\title{
Health beliefs, behaviour and determining factors in breast self - examination among a group of university students
}

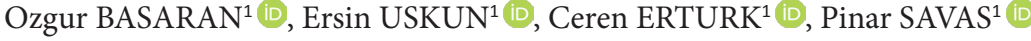 \\ 1 Department of Public Health, School of Medicine, Suleyman Demirel University, Isparta, Turkey \\ Corresponding Author: Ozgur BASARAN ～E-mail: ozgur.basaran@yahoo.com
}

Submitted: $03.06 .2019 \quad$ Accepted: 27.08.2019

\begin{abstract}
Objectives: Breast cancer is the most frequent malignancy in both Turkey and the World. Breast self-examination (BSE) is the cheapest and the easiest method for early detection. According to Turkey's Ministry of Health, 65.1 percent of women have never performed BSE. Only 10.1 percent of women perform BSE monthly. The purpose of this study was to examine health beliefs, behaviour and determining factors in BSE among a group of university students.

Materials and Methods: This cross-sectional analytical study was carried out with 15,940 female university students in 2016 . Sample size was 912. The research data was collected using a self-report questionnaire form and the adapted Turkish version of Champion's Health Belief Model Scale (CHBMS).

Results: Ten point four percent of students $(n=91)$ reported that they performed BSE monthly. Monthly BSE rates were higher in the students who were educated about BSE, who knew BSE timing and technique, who had been performed clinical breast examination and whose confidence subscale of CHBMS was higher.

Conclusion: In conclusion, health education programs should include BSE education in high schools and universities. Also, these education programs should include all women and relate to the confidence subscale of CHBMS.

Keywords: Health behaviour, Breast self-examination, Breast cancer
\end{abstract}

\section{INTRODUCTION}

Breast cancer is the most common type of cancer among women in both the World and Turkey. Age standardized frequency of the disease is $43.1 / 100.000$ in the World and 45.9/100.000 in Turkey [1,2].

Early diagnosis of breast cancer improves the efficacy of treatment and extends the life span of the patient. Mammography, breast ultrasonography, clinical breast examination, and breast self examination (BSE) may be performed for early detection of breast cancer. The cheapest and most effortless method is BSE.

Breast self-examination, is the regular, monthly inspectionpalpation examination of one's own breast. After twenty years of age every women should perform BSE regularly between 7 th 10th days of their menstrual period every month [3]. Regularly performed BSE is the simplest, most economical method for early detection of breast cancer and can be easily applied at home alone.

According to Turkish Ministry of Health data, 65.1\% of women over the age of 18 in Turkey never performed BSE. The prevalence of monthly and regularly performed BSE was $10.1 \%$ [4].
The Health Belief Model is one of the psychosocial models that explains the attitudes and beliefs that affect individuals' health behaviours. According to this model: the main factors affecting the health behaviours of individuals are: perceived susceptibility, perceived severity, perceived benefits, perceived barriers, confidence and general health motivation. It can be used to guide health promotion and disease prevention programs.

The purpose of this study is to determine the prevalence of BSE and the health beliefs related to BSE among female university students over 18 years of age and examine the factors affecting the outcome.

\section{MATERIALS and METHODS}

Type of Research, Sample (Universe) and Sampling Method

The cross-sectional analytical type of work was carried out with 15,940 female university students over the age of 18 during the 2015-2016 academic year.

How to cite this article: Basaran O, Uskun E, Erturk Yurttas C, Savas P. Health beliefs, behaviour and determining factors in breast self-examination among a group of university students. Marmara Med J 2019; 32: 130-136. doi: 10.5472/marumj.638115 
We selected the number of female students to be evaluated from the total number of female students attending 17 faculties at our university. The selected female students represented the total number of female students at the 17 faculties, in other words, they represented the total universe. The sample of the research was selected using stratified and simple random sampling methods. A total of 877 students were reached because of lack of attendance to school and not accepting to participate in the survey (Level of access 96.2\%).

\section{Data Collection Method}

The data was collected through the application of Sociodemographic Data Form prepared by the researchers and the Champion's Health Belief Model Scale (CHBMS) under observation.

Socio-demographic Data Form consisted of 26 questions about socio-demographic characteristics of the students (age, marital status, faculty, maternal age, maternal education, maternal employment status, family economic status, smoking and alcohol intake status) and information related to BSE (health related course attendance, BSE related education, interest for breast cancer / examination, status for having clinical breast examination, mammography and breast ultrasonography, knowing the best time for BSE, the right technique for BSE and the knowledge of risk groups, to whom BSE should be performed, presence of first degree relatives with breast cancer diagnosis, status for performing BSE and frequency).

Champion's Health Belief Model Scale, which is used to determine students' health beliefs about BSE, is a scale developed by Champion and revised in 1999 and adapted to Turkish by Karayurt and Dramalı [5,6]. The scale is a 42 -item form consisting of six sub-dimensions (perceived susceptibility, perceived seriousness, perceived benefits, perceived barriers, confidence and general health motivation). The answers given to each question are of 5 likert type ranging from "absolutely disagree" (1 point) to "strongly agree" (5 points) and each of the subscales of the scale is evaluated within itself. Perceived susceptibility subscale consists of 3 questions, perceived seriousness subscale consists of 7 questions, perceived benefits subscale consists of 4 questions, perceived barriers subscale consists of 11 questions, confidence subscale consists of 10 questions and general health motivation subscale consists of 7 questions.

The scores that correspond to answers given to a questions in each subscale were collected. As the scores increased, the level of perception in that subscale increased.

\section{Variables of Research}

Dependent variables of the study were scores obtained from the health beliefs subscale of BSE and regular BSE practice every month.

Independent variables of the study included: age, marital status, study in a health related faculty, mother's age, educational level and working status, economic status of the family, smoking and alcohol intake, attending courses on health sciences, education on BSE, interest in breast cancer and BSE, having clinical breast examination, having mammography and breast ultrasonography, knowing the right time for BSE, knowing the right technique for BSE, knowing the risk groups for BSE, having first degree relatives or close relatives with breast cancer diagnosis. Performing BSE at least once a month was considered as regular BSE. Subscales of CHBMS were taken as independent variables while variables related to regular BSE status were examined.

\section{Ethical Permissions}

Ethical approval was given by Suleyman Demirel University School of Medicine Clinical Research Ethics Committee (Approval number: 113). Before the start of the study, students were informed about the research and informed consent was obtained, and necessary permissions were obtained from the university in order to carry out the research.

\section{Evaluation of Data}

Data was assessed using descriptive statistics (number, percentage, mean, standard deviation), t-test in independent groups, Mann-Whitney $U$ test, Pearson correlation and chisquare tests in the statistical package program (SPSS, Version 17.0). Statistical significance level was accepted as $p<0.05$. In the analysis of the data, parametric tests were used where the variables provided parametric conditions ( $\mathrm{n} \geq 30$ and normal distribution was appropriate). The normal distribution of variables was evaluated using Kolmogorov Smirnov test.

Logistic regression analysis was used to identify independent predicators for regular performance of BSE. Variables that affected regular BSE and differed significantly in univariate analyses were age, education in a health-related faculty, mother's age and employment status, smoking status, attending courses on health sciences, education about BSE, interest in breast cancer and BSE, having clinical breast examination, having mammography and breast ultrasonography, knowing the right time for BSE, knowing the right technique for BSE, and knowing the risk groups for BSE. CHBMS subscale scores were entered into a logistic regression model. In logistic regression analysis, it is suggested to examine the correlations between variables to avoid multiple linkage, and to model only one of the variables that correlates with each other at a high level [those with correlation coefficients ( $r$ or rho) above 0.80] [7]. Since, there was no independent variable with correlation coefficient over 0.80 in the correlation analysis of the variables to be included in the logistic regression model, all variables listed above were left in the model in our study. Logistic regression analysis was performed by the "enter" method and model fit was assessed by the Hosmer and Lemeshow test. As a high p value was obtained from the Hosmer and Lemeshow test, it was decided that the model was a high predictive model $\left(\mathrm{X}^{2}=4.020\right.$, Degrees of Freedom $(\mathrm{df})=8, \mathrm{p}>0.05)$. 


\section{RESULTS}

The descriptive characteristics of the group are presented in Tables I and II. Fifty-six point one percent $(n=492)$ of the group were under 21 years of age, $97.8 \%(n=858)$ were single and $15.1 \%(\mathrm{n}=132)$ were educated in a health related faculty. The average age of the study group was $21.3 \pm 2.2$ and the mean age of the mothers was $47.0 \pm 5.7$. Sixty-five point one percent of the mothers were 45 years old or over, $64.9 \%(n=569)$ had primary education and $25.9 \%$ were working $(n=227)$. Among the study group, $97.4 \%(\mathrm{n}=854)$ of the families had medium or good economic status. Forty point nine percent of the students $(n=359)$ were smoking and $43.1 \%(n=378)$ were alcohol intaker.

The characteristics of the study group regarding breast cancer family history and early diagnosis are shown in Table II. Among individuals $23.7 \%(\mathrm{n}=208)$ were taking health related courses and $36.1 \%(n=317)$ were trained in BSE. Seventy one point four percent $(n=626)$ of the group stated that they were interested in BSE and breast cancer. Clinical breast examination was performed by a physician in $16.0 \%(\mathrm{n}=140)$ of individuals, mammography was performed in $3.4 \%(\mathrm{n}=30)$ and breast ultrasonography was performed in $9.9 \%(n=87)$ of the individuals. Among the study group; $29.4 \%(n=258)$ knew the most suitable time for BSE, $17.2 \%(\mathrm{n}=151)$ knew the technique and $71.8 \%(\mathrm{n}=630) \mathrm{knew}$ risky groups correctly. There was a first-degree relative in $1.7 \%$ of individuals in this study $(n=15)$ with a diagnosis of breast cancer and on the other hand $21.3 \%$ $(\mathrm{n}=187)$ of the participants had a relative or a friend with breast cancer diagnosis.

In the study group, $10.4 \%(\mathrm{n}=91)$ of the individuals were regularly performing BSE every month (Figure 1). Students who were over the age of twenty-two, those who were educated in a health-related faculty, those with a mother aged 45 or over, those whose mothers were working and non-smokers were significantly more likely to perform BSE regularly $(\mathrm{p}<0.01$, $\mathrm{p}<0.001, \mathrm{p}<0.01, \mathrm{p}<0.05$ and $\mathrm{p}<0.05$, respectively) (Table I).

BSE Regularity Among Students

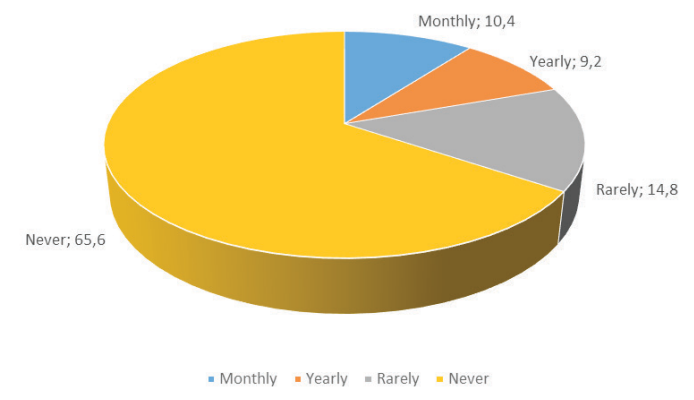

Figure 1. Breast self-examination regularity among students

The prevalence of regular BSE in individuals who attended courses on health sciences, had education on BSE, had interest in breast cancer and BSE, had clinical breast examination, had mammography and breast ultrasonography and those who knew the right time and the right technique for BSE, knew the risk groups for BSE was significantly higher when compared with the findings of others $(\mathrm{p}<0.001, \mathrm{p}<0.001, \mathrm{p}<0.001, \mathrm{p}<0.001$, $\mathrm{p}<0.001, \mathrm{p}<0.001, \mathrm{p}<0.001$ and $\mathrm{p}<0.001$, respectively) (Table II).

Champion's Health Belief Model Scale point averages for the subscales ( \pm Standard Deviation) in our study were found as follows: $8.1 \pm 2.7$ for the perceived susceptibility subscale (lowest and highest possible scores 3-15), 22.7 \pm 5.7 for perceived seriousness subscale (lowest and highest possible scores 7-35), 15.3 \pm 3.7 for perceived benefits subscale (lowest and highest possible scores $4-20), 28.1 \pm 7.6$ for perceived barriers subscale (lowest and highest possible scores 11-55), 31.1 \pm 8.8 for confidence subscale (lowest and highest possible scores 10-50) and 25.1 \pm 5.4 for general health motivation subscale (lowest and highest possible scores 7-35). Correlations between CHBMS subscale scores for our study group are presented in Table III.

In individuals who performed BSE regularly: perceived benefits, confidence and general health motivation subscale scores were significantly higher than the others and on the other hand, perceived barriers subscale score was significantly low $(\mathrm{p}<0.001$, $\mathrm{p}<0.001, \mathrm{p}<0.001$ and $\mathrm{p}<0.001$, respectively) (Table IV).

Perceived susceptibility subscale scores of students whose mothers aged 45 or over and economic condition was bad, who were smokers and alcohol intakers, who had BSE education before, who were interested in BSE and breast cancer, who knew the correct time for BSE and who had first degree relatives or close relatives with breast cancer diagnosis, were significantly higher than the scores of others, $(\mathrm{p}<0.01, \mathrm{p}<0.01, \mathrm{p}<0.05, \mathrm{p}<0.05$, $\mathrm{p}<0.05 \mathrm{p}<0.001, \mathrm{p}<0.001, \mathrm{p}<0.01$ and $\mathrm{p}<0.01$, respectively) (Tables I and II).

The average of the perceived seriousness subscale score of those who knew the most suitable time for BSE was significantly higher than the scores of the other students $(\mathrm{p}<0.05)$ (Table II).

The average perceived benefits subscale scores of the individuals who were trained in a health related faculty, attended courses on health sciences, had education about BSE, had interest in breast cancer and BSE, had clinical breast examination, had mammography and breast ultrasonography, who knew the right time for BSE, knew the right technique for BSE, the risk groups for BSE, were significantly higher than the scores of other attendants $(\mathrm{p}<0.001, \mathrm{p}<0.001, \mathrm{p}<0.001, \mathrm{p}<0.001, \mathrm{p}<0.05, \mathrm{p}<0.05$, $\mathrm{p}<0.01, \mathrm{p}<0.001, \mathrm{p}<0.001$ and $\mathrm{p}<0.01$, respectively) (Tables I and II).

Perceived barriers subscale averages of the students who were under 21 years old, single, trained in a faculty rather than in a health related one, and who attended courses on health sciences, and who did not have training on BSE, who had interest in breast cancer and BSE, who had clinical breast examination, mammography and breast ultrasonography, and who did not know the right time for BSE, the right technique for BSE, the risk groups for BSE and who did not have any first-degree relatives with breast cancer diagnosis, were significantly higher than others $(\mathrm{p}<0.01, \mathrm{p}<0.05, \mathrm{p}<0.001, \mathrm{p}<0.01, \mathrm{p}<0.001, \mathrm{p}<0.001$, $\mathrm{p}<0.001, \mathrm{p}<0.01, \mathrm{p}<0.05, \mathrm{p}<0.01, \mathrm{p}<0.01, \mathrm{p}<0.001, \mathrm{p}<0.001$ and $\mathrm{p}<0.05$, respectively) (Tables I and II). 
Table I. The relationship between descriptictive characteristics and regular BSE and CHBMS subscale points among research group

\begin{tabular}{|c|c|c|c|c|c|c|c|c|c|c|}
\hline \multirow{2}{*}{\multicolumn{2}{|c|}{ Descriptive Characteristics }} & \multirow[b]{2}{*}{$\mathbf{n}$} & \multirow[b]{2}{*}{ Percent } & \multirow{2}{*}{$\begin{array}{l}\text { Regular BSE } \\
\text { [n (Percent)] }\end{array}$} & \multicolumn{6}{|c|}{ CHBMS Subscale Points (Mean \pm Standard Deviation) } \\
\hline & & & & & $\begin{array}{l}\text { Susceptibility } \\
\text { Perception }\end{array}$ & $\begin{array}{l}\text { Seriousness } \\
\text { Perception }\end{array}$ & $\begin{array}{l}\text { Benefits } \\
\text { Perception }\end{array}$ & $\begin{array}{l}\text { Barriers } \\
\text { Perception }\end{array}$ & Confidence & $\begin{array}{l}\text { General Health } \\
\text { Motivation }\end{array}$ \\
\hline \multirow{2}{*}{ Age } & Under 21 & 492 & 56.1 & $37(7.5)$ & $8.1 \pm 2.7$ & $22.5 \pm 5.8$ & $15.1 \pm 3.7$ & $28.8 \pm 7.4$ & $30.4 \pm 8.4$ & $24.7 \pm 5.5$ \\
\hline & Above 22 & 385 & 43.9 & $54(14.0)^{\star *}$ & $8.1 \pm 2.6$ & $22.8 \pm 5.5$ & $15.5 \pm 3.7$ & $27.3 \pm 7.9^{* *}$ & $32.1 \pm 9.2^{* *}$ & $25.7 \pm 5.2^{\star *}$ \\
\hline \multirow{2}{*}{ Marital status } & Single & 858 & 97.8 & $87(10.1)$ & $8.1 \pm 2.6$ & $22.6 \pm 5.7$ & $15.3 \pm 3.7$ & $28.2 \pm 7.6$ & $31.1 \pm 8.8$ & $25.1 \pm 5.4$ \\
\hline & Married & 19 & 2.2 & $4(21.1)$ & $7.4 \pm 2.7$ & $23.7 \pm 6.1$ & $16.3 \pm 4.4$ & $24.8 \pm 9.9^{*}$ & $30.1 \pm 8.8$ & $26.2 \pm 5.5$ \\
\hline \multirow{2}{*}{ Faculty } & Health Related & 132 & 15.1 & $44(33.3)$ & $8.3 \pm 2.8$ & $22.6 \pm 5.6$ & $16.6 \pm 3.3$ & $24.2 \pm 7.8$ & $38.1 \pm 7.9$ & $26.8 \pm 5.3$ \\
\hline & Others & 745 & 84.9 & $47(6.3)^{* * *}$ & $8.1 \pm 2.6$ & $22.7 \pm 5.7$ & $15.0 \pm 3.8^{* * *}$ & $28.9 \pm 7.4^{* * *}$ & $29.9 \pm 8.3^{* * *}$ & $24.8 \pm 5.4^{\star * *}$ \\
\hline \multirow{2}{*}{ Mother's age } & Under 44 & 306 & 34.9 & $17(5.6)$ & $7.7 \pm 2.4$ & $22.4 \pm 5.3$ & $15.1 \pm 3.9$ & $28.1 \pm 6.9$ & $29.8 \pm 8.8$ & $24.6 \pm 5.3$ \\
\hline & Above 45 & 571 & 65.1 & $74(13.0)^{\star \star}$ & $8.3 \pm 2.6^{* *}$ & $22.8 \pm 5.9$ & $15.4 \pm 3.7$ & $28.2 \pm 8.0$ & $31.9 \pm 8.7^{\star *}$ & $25.4 \pm 5.5^{*}$ \\
\hline \multirow{2}{*}{$\begin{array}{l}\text { Mother's } \\
\text { educational status }\end{array}$} & Middle School & 569 & 64.9 & $51(9.0)$ & $8.1 \pm 2.7$ & $22.6 \pm 5.5$ & $15.2 \pm 3.7$ & $28.1 \pm 7.5$ & $30.8 \pm 8.7$ & $25.3 \pm 5.3$ \\
\hline & $\begin{array}{l}\text { Higher } \\
\text { Education }\end{array}$ & 308 & 35.1 & $40(13.0)$ & $8.1 \pm 2.6$ & $22.7 \pm 6.1$ & $15.4 \pm 3.9$ & $28.1 \pm 7.9$ & $31.8 \pm 8.9$ & $24.9 \pm 5.7$ \\
\hline \multirow{2}{*}{$\begin{array}{l}\text { Mother's working } \\
\text { status }\end{array}$} & Working & 227 & 25.9 & $32(14.1)$ & $8.4 \pm 2.7$ & $22.7 \pm 6.0$ & $15.3 \pm 3.8$ & $28.2 \pm 8.0$ & $31.7 \pm 8.6$ & $24.9 \pm 5.5$ \\
\hline & Not Working & 650 & 74.1 & $59(9.1)^{*}$ & $8.0 \pm 2.6$ & $22.7 \pm 5.6$ & $15.2 \pm 3.7$ & $28.1 \pm 7.5$ & $30.9 \pm 8.8$ & $25.2 \pm 5.4$ \\
\hline \multirow{2}{*}{$\begin{array}{l}\text { Economic } \\
\text { status of the family }\end{array}$} & High or Middle & 854 & 97.4 & $87(10.2)$ & $8.0 \pm 2.6$ & $22.6 \pm 5.7$ & $15.3 \pm 3.7$ & $28.1 \pm 7.6$ & $31.1 \pm 8.8$ & $25.2 \pm 5.4$ \\
\hline & Low & 23 & 2.6 & $4(17.4)$ & $9.8 \pm 3.0^{* *}$ & $24.0 \pm 6.3$ & $15.1 \pm 3.7$ & $31.2 \pm 9.4$ & $33.1 \pm 8.6$ & $24.2 \pm 4.9$ \\
\hline \multirow{2}{*}{ Smoking } & Not Smoking & 518 & 59.1 & $64(12.4)$ & $7.9 \pm 2.7$ & $22.6 \pm 5.7$ & $15.3 \pm 3.8$ & $27.5 \pm 7.6$ & $31.2 \pm 9.1$ & $25.6 \pm 5.5$ \\
\hline & Smoking & 359 & 40.9 & $27(7.5)^{*}$ & $8.3 \pm 2.6^{*}$ & $22.8 \pm 5.7$ & $15.3 \pm 3.6$ & $29.1 \pm 7.6^{\star *}$ & $31.1 \pm 8.2$ & $24.4 \pm 5.3^{\star *}$ \\
\hline \multirow{2}{*}{ Alcohol intake } & Not Drinking & 499 & 56.9 & $53(10.6)$ & $7.9 \pm 2.7$ & $22.8 \pm 5.7$ & $15.2 \pm 3.9$ & $28.0 \pm 7.6$ & $30.8 \pm 8.8$ & $25.4 \pm 5.6$ \\
\hline & Drinking & 378 & 43.1 & $38(10.1)$ & $8.3 \pm 2.6^{*}$ & $22.5 \pm 5.7$ & $15.4 \pm 3.5$ & $28.4 \pm 7.7$ & $31.6 \pm 8.7$ & $24.8 \pm 5.1$ \\
\hline \multicolumn{2}{|l|}{ Total } & 877 & 100.0 & $91(10.4)$ & $8.1 \pm 2.7$ & $22.7 \pm 5.7$ & $15.3 \pm 3.7$ & $28.1 \pm 7.6$ & $31.1 \pm 8.8$ & $25.1 \pm 5.4$ \\
\hline
\end{tabular}

${ }^{*} \mathrm{p}<0.05,{ }^{* *} \mathrm{p}<0.01,{ }^{* *} \mathrm{p}<0.001$, BSE: Breast Self Examination, CHBMS: Champion’s Health Belief Model Scale, $\mathrm{n}$ : Number

Table II. The relationship between characteristics about breast cancer and regular BSE and CHBMS subscale points among research group

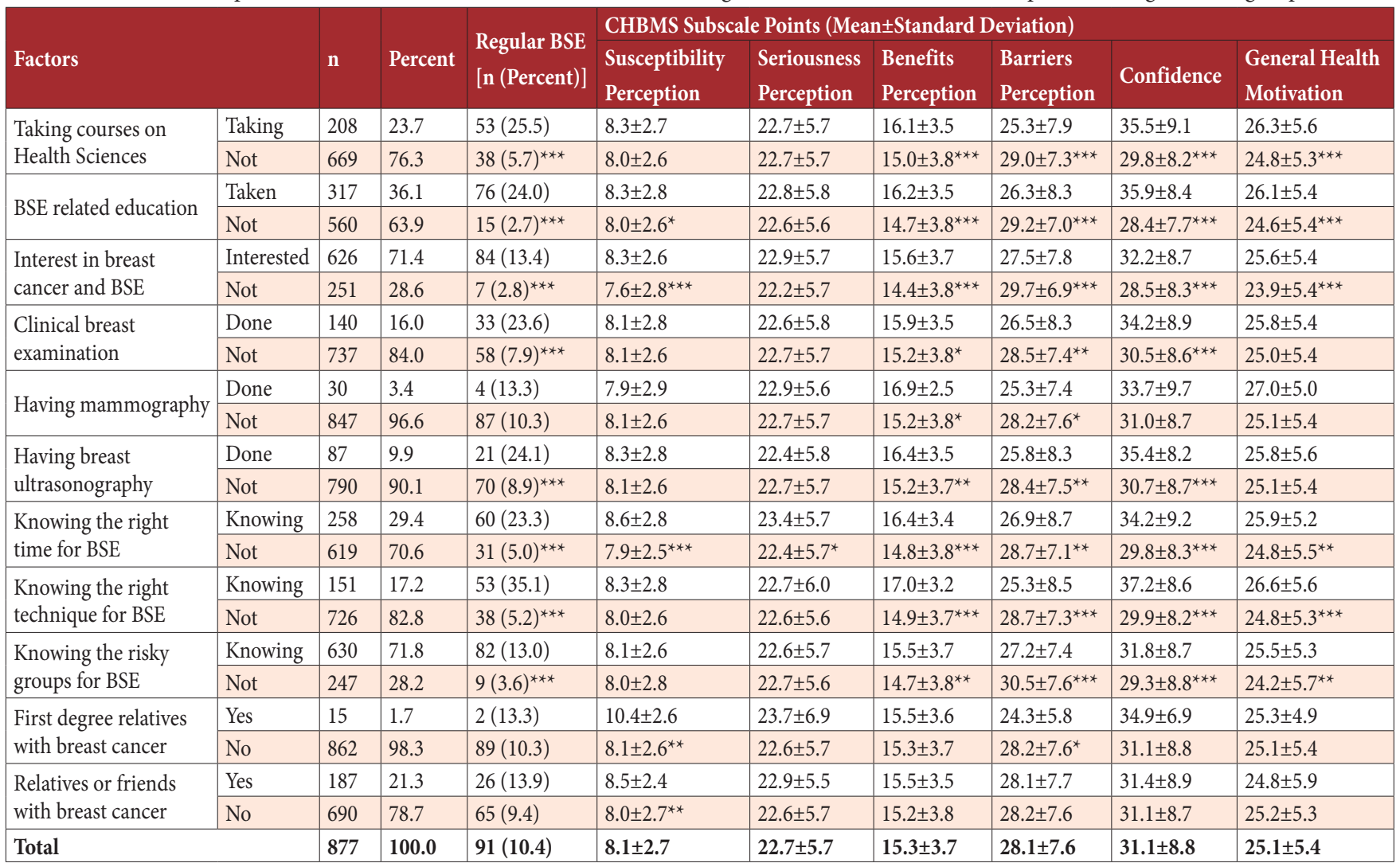

${ }^{*} \mathrm{p}<0.05 ;{ }^{* *} \mathrm{p}<0.01 ;{ }^{* *} \mathrm{p}<0.001$, BSE: Breast Self Examination, CHBMS: Champion’s Health Belief Model Scale, n: Number 
Table III. Correlation between CHBMS subscale points

\begin{tabular}{|c|c|c|c|c|c|c|}
\hline \multirow[b]{2}{*}{ CHBMS Subscale Points (r) } & \multicolumn{6}{|c|}{ CHBMS Subscale Points (r) } \\
\hline & $\begin{array}{l}\text { Perceived } \\
\text { Susceptibility }\end{array}$ & Perceived Seriousness & Perceived Benefits & Perceived Barriers & Confidence & $\begin{array}{l}\text { General Health } \\
\text { Motivation }\end{array}$ \\
\hline $\begin{array}{l}\text { Perceived } \\
\text { Susceptibility }\end{array}$ & 1.000 & $0.277^{* * *}$ & 0.056 & $0.128^{* * *}$ & $0.118^{* * *}$ & -0.033 \\
\hline $\begin{array}{l}\text { Perceived } \\
\text { Seriousness }\end{array}$ & $0.277^{* * *}$ & 1.000 & $0.195^{* * *}$ & $0.138^{* * *}$ & 0.038 & $0.106^{* *}$ \\
\hline $\begin{array}{l}\text { Perceived } \\
\text { Benefits }\end{array}$ & 0.056 & $0.195^{* * *}$ & 1.000 & $-0.215^{* * *}$ & $0.302^{* * *}$ & $0.353^{* *}$ \\
\hline $\begin{array}{l}\text { Perceived } \\
\text { Barriers }\end{array}$ & $0.128^{* * *}$ & $0.138^{* * *}$ & $-0.215^{* * *}$ & 1.000 & $-0.209^{* * *}$ & $-0.254^{* * *}$ \\
\hline Confidence & $0.118^{* * *}$ & 0.038 & $0.302^{* * *}$ & $-0.209^{* * *}$ & 1.000 & $0.287^{* * *}$ \\
\hline General Health Motivation & -0.033 & $0.106^{* *}$ & $0.353^{* *}$ & $-0.254^{\star * *}$ & $0.287^{* * *}$ & 1.000 \\
\hline
\end{tabular}

${ }^{*} \mathrm{p}<0.05,{ }^{* *} \mathrm{p}<0.01,{ }^{* *} \mathrm{p}<0.001$, CHBMS: Champion's Health Belief Model Scale, $\mathrm{r}$ : Pearson's Corelation Coefficient

Table IV. The relationship between CHBMS subscale points and regular BSE performing

\begin{tabular}{|l|l|l|}
\hline \multirow{2}{*}{ CHBMS Subscales } & \multicolumn{2}{|l|}{ Regular BSE Performing } \\
\cline { 2 - 3 } & $\begin{array}{l}\text { Regular } \\
(\text { Mean } \pm \text { Standard } \\
\text { Deviation) }\end{array}$ & $\begin{array}{l}\text { Not Regular or None } \\
\text { (Mean } \pm \text { Standard } \\
\text { Deviation) }\end{array}$ \\
\hline Perceived susceptibility & $8.5 \pm 2.9$ & $8.0 \pm 2.6$ \\
\hline Perceived seriousness & $23.1 \pm 6.1$ & $22.6 \pm 5.6$ \\
\hline Perceived benefits & $17.0 \pm 3.4^{* * *}$ & $15.1 \pm 3.7$ \\
\hline Perceived barriers & $23.9 \pm 8.9^{* * *}$ & $28.6 \pm 7.3$ \\
\hline Confidence & $40.0 \pm 7.2^{* * *}$ & $30.1 \pm 8.3$ \\
\hline General health motivation & $27.7 \pm 4.9^{* * *}$ & $24.8 \pm 5.4$ \\
\hline
\end{tabular}

${ }^{* * *} \mathrm{p}<0.001, \mathrm{CHBMS}$ : Champion's Health Belief Model Scale, BSE: Breast SelfExamination

Table V. Logistic regression analyses of the factors for regular BSE

\begin{tabular}{|l|l|}
\hline Factors & OR $(\mathbf{9 5} \% \mathbf{C I})$ \\
\hline Age (Above 22) & $0.7(0.4-1.2)$ \\
\hline Faculty (Health Related) & $0.8(0.3-2.2)$ \\
\hline Mother's age (Above 45) & $1.6(0.8-3.1)$ \\
\hline Mother's working status (Working) & $1.6(0.9-2.9)$ \\
\hline Smoking (Not Smoking) & $1.4(0.8-2.5)$ \\
\hline Attending courses on Health Sciences & $2.1(0.8-5.4)$ \\
\hline BSE related education (Taken) & $2.4^{*}(1.2-5.0)$ \\
\hline Interest in breast cancer and BSE & $2.1(0.9-5.1)$ \\
\hline Clinical breast examination & $3.2^{* *}(1.4-7.6)$ \\
\hline Having breast ultrasonography & $1.0(0.4-2.7)$ \\
\hline Knowing the right time for BSE & $1.9^{*}(1.0-3.5)$ \\
\hline Knowing the right technique for BSE & $3.0^{* *}(1.5-5.7)$ \\
\hline Knowing the risky groups for BSE & $1.7(0.8-4.0)$ \\
\hline Perceived Susceptibility & $1.1(0.9-1.2)$ \\
\hline Perceived Seriousness & $1.0(1.0-1.1)$ \\
\hline Perceived Benefits & $0.9(0.9-1.0)$ \\
\hline Perceived Barriers & $1.0(0.9-1.0)$ \\
\hline Confidence & $1.1^{* *}(1.0-1.1)$ \\
\hline General health motivation & $1.0(1.0-1.1)$ \\
\hline
\end{tabular}

${ }^{*} \mathrm{p}<0.05,{ }^{* *} \mathrm{p}<0.01,{ }^{* *} \mathrm{p}<0.001, \mathrm{BSE}$ : Breast Self Examination, OR= Odds Ratio, $\mathrm{CI}=$ Confidence Interval
Confidence subscale averages of individuals who were 22 years old and over, were trained in a health related faculty, whose mothers were 45 years old and over, who were taking lessons about health sciences, who had education on BSE, who had interest in breast cancer and BSE, who had clinical breast examination, who had breast ultrasonography, who knew the right time and the technique for BSE and who knew the risk groups for BSE, were significantly higher than the findings of other students $(\mathrm{p}<0.01, \mathrm{p}<0.001, \mathrm{p}<0.01, \mathrm{p}<0.001, \mathrm{p}<0.001$, $\mathrm{p}<0.001, \mathrm{p}<0.001, \mathrm{p}<0.001, \mathrm{p}<0.001, \mathrm{p}<0.001$ and $\mathrm{p}<0.001$, respectively) (Tables I and II).

General health motivation subscale averages of individuals who were 22 years old or over, trained in a health related faculty, whose mother was 45 years old or over, were taking lessons about health sciences, and who had education on BSE, who had interest in breast cancer and BSE, who had clinical breast examination, breast ultrasonography, and who knew the right time and the technique for BSE and the risk groups for BSE, were significantly higher than the values of other participants $(\mathrm{p}<0.01, \mathrm{p}<0.001, \mathrm{p}<0.05, \mathrm{p}<0.01, \mathrm{p}<0.001, \mathrm{p}<0.001, \mathrm{p}<0.001$; $\mathrm{p}<0.01, \mathrm{p}<0.001$ and $\mathrm{p}<0.01$, respectively) (Tables I and II).

The results of the logistic regression analysis that we conducted to determine the independent predictors of the prevalence of regular BSE are presented in Table V. Having education on BSE $(\mathrm{OR}=2.4, \mathrm{p}<0.05)$, having clinical breast examination $(\mathrm{OR}=3.2$, $\mathrm{p}<0.01)$, knowing the right time for $\mathrm{BSE}(\mathrm{OR}=1.9, \mathrm{p}<0.05)$, knowing the right technique for $\mathrm{BSE}(\mathrm{OR}=3.0, \mathrm{p}<0.01)$, and trust / self efficacy subscale scores affected BSE $(\mathrm{OR}=1.1, \mathrm{p}<0.01)$.

\section{DISCUSSION}

The study was conducted in order to find out the prevalence of BSE among university students. Regularly performed BSE every month was found to be $10.4 \%$. Thirty two percent of Arabic refugee women in Canada performed BSE regularly. [8] In previous studies conducted in Turkey, higher ratios were found especially in nursing students $(31 \%, 32 \%, 53 \%)$ but our ratio is similar with Karayurt, et al., who conducted a study on 193 university students from various faculties (6.2\%) [9-12]. 
Sapountzi-Krepia et al., also found that the ratio of nursing students in Cyprus who performed regular BSE for more than a year as $10.9 \%$ [13]. Besides, in 2014 Health Statistics Yearbook, published by Turkish Ministry of Health, it was reported that $10.1 \%$ of women regularly performed BSE every month [4].

Subscale point averages of CHBMS ( \pm Standard Deviation) in our study were found as follows: $8.1 \pm 2.7$ for the perceived susceptibility subscale, $22.7 \pm 5.7$ for the perceived seriousness subscale, $15.3 \pm 3.7$ for the perceived benefits subscale, 28.1 \pm 7.6 for perceived barriers subscale, $31.1 \pm 8.8$ for confidence subscale and $25.1 \pm 5.4$ for general health motivation subscale. Karayurt et al., studied the effects of peer and group education on knowledge and belief on breast cancer and BSE. In their study, CHBMS subscale point averages for peer and group education were found as follows: $8.6 \pm 2.9$ and $8.1 \pm 1.6$ for the susceptibility perception subscale, $20.5 \pm 7.2$ and $21.0 \pm 5.1$ for seriousness perception subscale, $14.1 \pm 5.9$ and $14.5 \pm 5.7$ for benefits perception subscale, $24.6 \pm 4.8$ and $24.5 \pm 5.3$ for barriers perception subscale, $26.8 \pm 9.6$ and $28.2 \pm 7.5$ for confidence subscale $24.3 \pm 5.3$ and $24.3 \pm 5.6$ for general health motivation subscale, respectively [10]. Karayurt et al., performed this study in Izmir, a city in the West part of Turkey, 10 years ago. The scores for barriers perception and confidence subscale scores in our study were higher than those obtained in Karayurt et al's study. This may be due to the date of the study or regional differences. Erbil and Bölükbaşı studied a group of policlinic patients and found subscale points as follows: susceptibility perception score $(7.5 \pm 2.5)$, seriousness perception score $(21.2 \pm 5.5)$, benefits perception score (15.0 \pm 3.8$)$, barriers perception score $(27.0 \pm 6.7)$, confidence score (32.0 \pm 6.7$)$, and general health motivation score $(25.1 \pm 5.6)$ [14]. Lower susceptibility perception score, in the study of Erbil and Bölükbaş1, when compared to those in our study might be due to the population of university students in our study. The average educational level of our universe was higher than the related study. This may have led to a high awareness of breast cancer in our universe that it may be seen in everyone so that the perceived susceptibility subscale may be high.

As a result of our logistic regression analysis, we determined that breast self-examination training was a predictor that increased the rate of regular BSE. Aker et al., also found in their logistic regression analysis that, being educated on breast health, increased BSE rate by 3.81 (95\% GA, 2.16-6.72) times [15]. Uzun et al., showed an increased ratio of performing BSE in undergraduate nursing students after education [12]. Özkahraman et al., conducted a study with trainee women in a public education center and detected that having information on BSE increased the ratio of performing BSE significantly [16]. Tuyen et al., reported that performing monthly BSE was negatively associated with receiving information on BSE [17]. Lee, in his study showed increased BSE training ratio but in regression analysis BSE training was not significant [18]. In conclusion, these results demonstrated that, education can positively change individuals' health beliefs.

Our regression analysis showed that clinical breast examination was a predictor of BSE performance ratio. In a study of Aksoy et al., on women over 40 years of age it was found that the rate of having a clinical breast examination was higher in regular BSE performers [19]. Clinical breast examination and information given by physicians on BSE might increase the awareness of the individuals on regular BSE.

In our logistic regression analysis, it was found that knowing the most appropriate time for BSE and the BSE technique correctly increased the BSE rate. Uncu, did not detect a significant relation between knowing the appropriate BSE technique and performing BSE. On the other hand, Lee showed in logistic regression analysis that BSE rate increasesd as BSE knowledge score increased $[18,20]$. Our findings showed that those who regularly performed BSE, knew the right time and technique for BSE. These results were similar with the above studies.

In our logistic regression analysis, it was determined that the BSE rate increased as the confidence / self-efficacy score increased. Spountzi-Krepia et al., Aker at al., Lee, and Lavdaniti showed that the ratio of BSE increased as trust/self efficiacy increased in logistic regression models $[13,15,18,21]$.

Although, the CHBMS perceived barriers subscale was found to be significant in univariate analysis in our study, it was found that regular regression model did not significantly affect BSE performance. In the studies of Aker et al., and Lee it was determined that the score of perceived barriers was a variable affecting the BSE ratio in the negative direction $[15,18]$. As seen in our univariate analysis results, as the barriers subscale scores increased, the rate of BSE was expected to increase.

By using the CHBMS for assessment, educators and primary health care providers can more easily understand the beliefs that influence women on breast cancer and BSE.

In conclusion,we detected in our regression model that being educated on BSE, knowing the best time for BSE and appropriate BSE technique and having a clinical breast examination regularly, increased the ratio of performing BSE.

We can conclude that education is the most appropriate tool that can be used to raise awareness on BSE. Considering the necessity of performing BSE starting from young ages, inclusion of BSE education in the curriculum of high schools and universities will also increase the rate of performing BSE. Also, we recommend that planned interactive training programs for breast cancer and BSE should be implemented for larger groups of women at Women's Health Centers and Family Centers. Further research is needed in order to measure the effectiveness of these trainings.

\section{REFERENCES}

[1] GLOBOCAN 2012: Estimated Cancer Incidence, Mortality and Prevalence Worldwide in 2012. http://globocan.iarc.fr/ Pages/fact_sheets_population.aspx. Accessed on 01.09.2016.

[2] Şencan İ, İnce GN. Türkiye Kanser İstatistikleri. Ankara: T. C. Sağlık Bakanlığı; 2016.

[3] İstanbul İl Sağllk Müdürlüğü Kendi Kendine Meme Muayenesi Tanıtım Broşürü. http://www.istanbulsaglik.gov.tr/w/sb/egt/ pdf/kkmm_brosur.pdf. Accessed on 01.09.2016.

[4] Başara BB, Güler C, Yentür GK. Sağlık İstatistikleri Yıllığ 2014. Ankara: Sentez Matbaacılık ve Yayıncılık: 2015. 
[5] Champion VL. Revised susceptibility, benefits, and barriers scale for mammography screening. Res Nurs Health 1999;22:341-8.

[6] Karayurt O, Dramalı A. Adaptation of Champion's Health Belief Model Scale for Turkish women and evaluation of the selected variables associated with breast self-examination. Cancer Nurs 2007;30:69-77.

[7] Kaşko Y. Çoklu bağlantı durumunda ikili (binary) lojistik regresyon modelinde gerçekleşen I. tip hata ve testin gücü. (The observed type I error and power of logistic regression model under multicollinearity) [Yüksek Lisans Tezi]. Ankara, Ankara Üniversitesi Fen Bilimleri Enstitüsü Zootekni Ana Bilim Dalı: 2007.

[8] Rasin L, Sithokozile M, Iş1 A. Breast cancer attitudes and beliefs among recent Islamic/Muslim refugee women in Canada. 30th International Nursing Research Congress: Theory-to-Practice: Catalyzing Collaborations to Connect Globally. Held 25-29 July 2019 in Calgary, Alberta, Canada. Poster Presentation.

[9] Aslan A, Temiz M, Yiğit Y, Can R, Canbolant E, Yiğit F. The knowledge attitude and behaviorus of nursery students about breast cancer. TAF Prev Med Bull 2007;6:193-8.

[10] Karayurt O, Dicle A, Malak AT. Effects of peer and group education on knowledge, beliefs and breast self-examination practice among university students in Turkey. Turk J Med Sci 2009;39:59-66. doi:10.3906/sag-0712-17

[11] Kılıç S, Uçar M, Seymen E, et al. Determination of the knowledge and practice level of breast self-examination among the nurses of the GATA hospital, the students of the GATA nursing school and some female patients. Gülhane Med J 2006;48:200-4.

[12] Uzun Ö, Karabulut N, Karaman Z. Hemşirelik öğrencilerinin kendi kendine meme muayenesi ile ilgili bilgi ve uygulamaları. Atatürk Universitesi Hemşirelik Yüksek Okulu Dergisi 2004;7:33-41.
[13] Sapountzi-Krepia D, Rekleiti M, Lavdaniti M, et al. Evaluating female nursing students' knowledge and attitudes regarding breast self-examination. Health Care Women Int 2017;38:78695. doi:10.1080/07399.332.2017.1326921

[14] Erbil N, Bölükbaş N. Beliefs, attitudes, and behavior of Turkish women about breast cancer and breast self-examination according to a Turkish version of the Champion Health Belief Model Scale. Asian Pac J Cancer Prev 2012;13:5823-8. doi:10.7314/APJCP.2012.13.11.5823

[15] Aker S, Öz H, Tunçel EK. Samsun'da yaşayan kadınların meme kanseri erken tanı yöntemleri ile ilgili uygulamaları ve bu uygulamaları etkileyen faktörlerin değerlendirilmesi. The J Breast Health 2015;11:115-22. doi:10.5152/tjbh.2015.2547

[16] Özkahraman Ş, Vural BK, Bayık A. Halk eğitim merkezi kursiyerlerinde kendi kendine meme muayene becerisi geliştirme. Journal of Anatolia Nursing and Health Sciences. 2006;9(4):1-9.

[17] Tuyen DQ, Dung Tv, Dong HV, Kien TT, Huong TT. Breast self-examination: knowledge and practice among female textile workers in Vietnam. Cancer Control 2019;26: 107.327.4819862788. doi: 10.1177/107.327.4819862788

[18] Lee E H. Breast self-examination performance among Korean nurses. J Nurses in Staff Dev 2003;19:81-7.

[19] Aksoy YE, Turfan EÇ, Sert E, Mermer G. Meme kanseri erken tanı yöntemlerine ilişkin engeller. J Breast Health 2015;11:2630. doi:10.5152/tjbh.2014.2296

[20] Uncu F, Bilgin N. Birinci basamak sağlık hizmetlerinde çalışan ebe ve hemşirelerin meme kanseri erken tanı uygulamaları konusunda bilgi, tutum ve davranışları. J Breast Health. 2011;7:167-75.

[21] Lavdaniti M. Perceptions and health beliefs of Greek nursing students about breast self-examination: A descriptive study. Int J Nurs Pract 2015;21:882-8. doi:10.1111/ijn.12323 